DOI: https://doi.org/10.15407/techned2018.06 $: \underline{050}$

\title{
INVESTIGATION OF PROPERTIES OF COMBINED SCHEME OF SINGLE-PHASE SWITCHING OF INDUCTION ELECTRIC DRIVE OF PUMPING PLANTS
}

Journal

Publisher

ISSN

Issue

Pages
Tekhnichna elektrodynamika

Institute of Electrodynamics National Academy of Science of Ukraine 1607-7970 (print), 2218-1903 (online)

No 6, 2018 (November/December)

$50-53$

\section{Authors}

\section{Yu.V. Shurub ${ }^{1 *}$, V.Y. Vasilenkov ${ }^{2}$, Yu.L. Tsitsyurskiy ${ }^{2}$}

1 - Institute of Electrodynamics National Academy of Sciences of Ukraine,

pr. Peremohy, 56, Kyiv, 03057, Ukraine,

e-mail: shurub@bigmir.net

2 - National University of Life and Environmental Sciences of Ukraine,

Heroyiv Oborony st., 15, Kyiv, 03041, Ukraine

* ORCID ID : http://orcid.org/0000-0002-2735-4613

\section{Abstract}

A combined circuit for single-phase switching of a voltage-controlled induction electric drive with a three-phase motor is proposed for pump plants, which allows to obtain satisfactory operational and power characteristics in starting and operating modes at a constant capacitance of a phase-shift capacitor. It is proved that it is possible to reduce power losses due to the use of different switching the circuits of the motor windings at different speed control ranges as compared to schemes with a constant structure. References 9, figures 5. 
Key words: induction electric drive, phase-shift capacitor, single-phase power supply.

Received: 05.03 .2018

Accepted: 17.05 .2018

Published: 23.10 .2018

\section{References}

1. Shurub Yu.V. Comparative analysis of circuit solutions of the power part of three-phase single-phase induction electric drives with parametric adjustment of coordinates and varying voltage. Visnyk Kremenchutskoho derzhavnoho politekhnichnoho universytetu: Naukovi pratsi KDPU 2002.

No 1(12). Pp. 71-74. (Rus)

2. Khizhniak T.A., Husev O.O., Lipinskyi I.S. Remote control of electromechanical devices in the climate control system. Tekhnichna Elektrodynamika. 2016. No 5. Pp. 32-34. DOI: https:// doi.org/10.15407/techned2016.05.032 (Ukr)

3. Lysenko V., Dudnyk A. Automation of Biotechnological Objects. Proc. $13^{\text {th }}$ International Conference on Modern Problems of Radio Engineering, Telecommunications and Computer Science TCSET2016

. Lviv, Ukraine, February 23-26, 2016. Pp. 44-46. DOI:

https://doi.org/10.1109/TCSET.2016.7451963

4. Bibik O.V., Popovych O.M., Shevchuk S.P. Power effective modes electromechanical system of pump installation of the multistorey building. Tekhnichna Elektrodynamika. 2016. No 5. Pp. 38-45. DOI:

https:/ /doi.org/10.15407/techned2016.05.038 (Ukr)

5. Malyar V., Hamola O., Maday V. Calculation of capacitors for starting up a three-phase 
asynchronous motor fed by single-phase power supply. Proc. $17^{\text {th }}$ International Conference on Computational Problems of Electrical Engineering CPEE2016

. Sandomierz, Poland, September 14-17, 2016. Pp. 1-4. DOI:

https://doi.org/10.1109/CPEE.2016.7738735

6. Eltamaly A.M., Alolah A.I., Hamouda R., Abdulghany M.Y. A novel digital implementation of $A C$ voltage controller for speed control of induction motor. International Journal of Power and Energy Conversion . 2010. Vol. 2.

No 1. Pp. 78-94. DOI:

https://doi.org/10.1504/IJPEC.2010.030862

7. Shurub Yu.V. Statistical optimisation of voltage regulated induction electric drives. Tekhnichn a Elektrodynamika

. 2014. No 5. Pp. 116-118. (Ukr)

8. Popovych O.M., Golovan I.V. Refinement of analysis operation of induction motors as part electromechanical systems using equivalenting field models using electrical circuits. Tekhnichn a Elektrodynamika

. 2014. No 5. Pp. 113-115. (Ukr)

9. Mazurenko L.I., Dzhura O.V., Shevchuk S.P. Transients in a Transistor-Switched Capacitor Regulator of a Stand-Alone Induction Generator Supplying a Single-Phase Load. Proc. International Conference on Modern Electrical and Energy Systems MEES2017 . Kremenchuk, Ukraine, November 15-17, 2017. Pp. 244-247. DOI:

https://doi.org/10.1109/MEES.2017.8248901

\section{PDF}

